ERRATUM OPEN

\title{
Erratum: Regulation of cancer epigenomes with a histonebinding synthetic transcription factor
}

David B. Nyer ${ }^{1}$, Rene M. Daer ${ }^{1}$, Daniel Vargas ${ }^{1}$, Caroline Hom ${ }^{1}$ and Karmella A. Haynes ${ }^{1}$

npj Genomic Medicine (2017)2:27; doi:10.1038/s41525-017-0029-0

Erratum to: npj Genomic Medicine (2017); doi:10.1038/s41525-0160002-3; Published 09 January 2017

The following text was erroneously included in the final publication (first paragraph of the Introduction, page 1): "Since the references were not in order it is has been rearranged it". This text has now been deleted in the HTML and PDF versions of this article.

Open Access This article is licensed under a Creative Commons Attribution 4.0 International License, which permits use, sharing, adaptation, distribution and reproduction in any medium or format, as long as you give appropriate credit to the original author(s) and the source, provide a link to the Creative Commons license, and indicate if changes were made. The images or other third party material in this article are included in the article's Creative Commons license, unless indicated otherwise in a credit line to the material. If material is not included in the article's Creative Commons license and your intended use is not permitted by statutory regulation or exceeds the permitted use, you will need to obtain permission directly from the copyright holder. To view a copy of this license, visit http://creativecommons. org/licenses/by/4.0/.

(c) The Author(s) 2017

${ }^{1}$ School of Biological and Health Systems Engineering, Arizona State University, 501 E Tyler Mall, Box 9709, Tempe, AZ 85287, USA Correspondence: Karmella A. Haynes (karmella.haynes@asu.edu)

Published online: 05 September 2017 